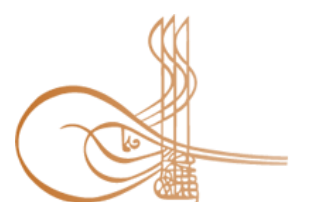

www.turkishstudies.net/social
Turkish Studies - Social Sciences

eISSN: 2667-5617

Research Article / Araștırma Makalesi

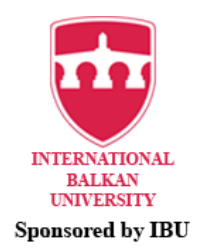

Sponsored by IBU

\title{
Kapadokya'da Kahraman ve Tanrı Herakles Kültü Üzerine Bir Değerlendirme
}

\author{
An Evaluation on the Cult of Heracles as Hero and God in Cappadocia
}

\author{
Meral Hakman*
}

\begin{abstract}
Greek religion played a major role in socio-cultural phase of the Hellenistic Period which started with Alexander the Great. Contrary to the other Anatolian regions, Cappadocia was very resistant and therefore the last to adapt to the new belief structure. Nevertheless, Greek gods and goddesses, religious practices, and agons were accepted and integrated into the local belief system during the Roman Imperial Period. Beliefs in Greek gods and goddesses such as Apollo, Artemis, Tykhe, Heracles, and especially Zeus practised their effect densely during various phases of Hellenistic Period. In this regard, this study evaluates the worship and cult of half mortal/half immortal Heracles based on the surviving evidence starting with the earliest examples. The primary sources of this study include the archaeological, epigraphical, and numismatic data on the cult of Heracles found in the cities of the region. The present study aims to explore how and where his belief was spread and accepted. It may be concluded from the existing data that the cult of Heracles emerged in the early second century B.C. and existed until the second century A.D. in the Cappadocia region. Additionally, it is seen that Heracles was worshipped there both as a half-immortal and as a god. In his worship as a half-immortal, Heracles was actually a divine hero and the protector of military training grounds and athletes. As a god, he served as the protector of cities.
\end{abstract}

Structured Abstract: Heracles is a different cult character in Greek religion as he is the son of Zeus and therefore a semigod. His half immortality provided a divine power for mortal humans and effected the development of his cult. Therefore, kings and emperors regarded themselves as Heracles, imitated him, used his attributes and reincarnated themselves just like him. It is known that statesmen such as Alexander the Great, Mithridates IV, and Roman Emperor Commodus used Heracles' transformation and divinity and posed like him in their sculptures. His half mortal character unveiled the divine might and power of moral mankind. Therefore, Heracles was worshipped almost like a god to acquire that power.

There are two types of worships in the cult of Heracles. It is known that he was worshipped as a mortal and divine hero (along with Hermes) in gymnasiums. In this type, he is the protector god of soldiers, military training fields, and athletes. The other type of his worship is people's regard for him as a protector of cities. It may actually be understood that his worship as a deity has developed from his first type. Nevertheless, Heracles does not depict the cult characterization of a complete Greek god. The most significant evidence in this regard is the tradition that his agons and rituals were carried on Zeus temples. The source of both worship types are Greek, and this dual structure may also be seen in Anatolia and Rome.

\footnotetext{
* Dr. Öğr. Üyesi, Aksaray Üniversitesi, Sabire Yazıc1 Fen Edebiyat Fakültesi, Arkeoloji Bölümü Asst. Prof. Dr., Aksaray University, Sabire Yazıcı Faculty of Science and Letters, Department of Archaeology ORCID 0000-0001-5968-7941 meralhakman@gmail.com

Cite as/ Atıf: Hakman, M. (2020). Kapadokya' da kahraman ve Tanrı Herakles kültü üzerine bir değerlendirme. Turkish Studies - Social, 15(5), 2543-2560. https://dx.doi.org/10.47356/TurkishStudies.44214

Received/Geliş: 13 June/Haziran 2020

Accepted/Kabul: 20 August/Ağustos 2020

Copyright (C INTAC LTD, Turkey
} 
This study analyses this dual typology which is also encountered in Cappadocia Region. The data on the cult of Heracles which was acquired from Caesarea and Tyana in Cappadocia prove that a local cult existed there. It is significant that the evidence for its existence in the region presents variety and continuity.

The oldest sculpture work of the region is the Heracles statute which was uncovered in Nigde Tepebaglari Mound. While this piece which is dated to Late Hellenistic and Early Roman Era depicts typological elements leading to a dilemma of Hermes and Heracles, it is mostly regarded as Heracles in terms of analogical evaluations. It must be a rather local figuration as Anatolian examples exist with similar typology. The rest of the works belong to Roman Empire Period. The (partial) Heracles statuette excavated in Tyana is significant for it depicts the structure of this cult. Dated to 2nd century B.C., Heracles seems to be depicted in resting Heracles pose. With the lion pose and club supported by a bull head, it is the cult statute of the protector of Tyana city. Another controversial piece is the old Heracles statute which is only known to have been found in Caesarea and dated to Roman Empire Period. Because its specific excavation site is unknown and no similar pieces are found, this statuette has not been subjected to proper analysis so as to clarify the characterization of the cult. It stands out compared to common tired Heracles type as both the face and the body are depicted as tiresome. In addition to these sculptures, there is a sarcophagus with Pamphylia friezes found in Caesarea. It is significant as it provides a depiction of Heracles' twelve labours and his chronological evolution into a god. It is undoubtedly an important reference to existence of his belief as Heracles' depictions were used on a sarcophagus.

The earliest epigraphical work is the Hanisa decree dated to 160 B.C. This piece is very significant as it speaks of the holy days organized in the name of Heracles pointing to the existence of the local cult. It is probable that the agon honouring Heracles was carried out in the temple of Zeus Stratios who is also mentioned in the inscription. This possibility is further enforced as Heracles rituals were customarily organized in Zeus temples. Another epigraphical data dated to 1st century B.C. is the Tyana inscription which points to the spread of the local cult as well as its continuity. Although both inscriptions mention the festivities honouring Heracles, it is a major lacking that they provide no information about the date, location, or the content of these events.

Numismatic evidences depict Heracles types such as his head with a lion coat around his shoulder and resting Heracles pictured with only a club or both a lion coat and a club. The earliest coin with Heracles depiction was uncovered in Caesarea and dated to the rule of Arkhelaos, the last king of Hellenistic Cappadocia. It is possible to find Heracles and related coins in Caesarea intermittently during Roman rule ending with Commodus. The earliest finding in Tyana is from Hadrian's rule, and the latest is an Julia Domna coin. Therefore, although there are some gaps, the numismatic data starts with Arkhelaos and continues until 2nd century B.C. When all the data which is related to Heracles is considered, the time span is from the middle of the $2^{\text {nd }}$ century B.C. to the $2^{\text {nd }}$ century A.D.

Consequently, it may be stated that the cult of Heracles became persistent in the region in the 2nd century B.C. when the intense Persian rule started to diminish and be replaced with Hellenistic culture. As the latest evidence is a Iulia Domna coin, it is understood that the cult existed even during the 2nd century B.C.. Finally, Heracles was worshipped both as a demi-god and a hero in Cappadocia Region during this period.

Keywords: Archaeology, Cappadocia, Herakles, Cult, Sculpture.

Öz: Büyük İskender ile başlayan Hellenistik Dönem'in sosyo-kültürel evresinde yani Hellenleşme sürecinde Yunan inancı etkin rol oynamıştır. Anadolu'nun diğer bölgelerinin tersine inanç bakımından Kapadokya, bu sürece en geç uyum sağlayan ve en çok direnen bölgelerin başında gelmektedir. Elbette, nihayetinde Yunan tanrı ve tanrıçaları, dini uygulamaları, agonları yerleşmiş; bölgenin kendi yerel yapısıyla bütünleşerek yayılımını Roma İmparatorluk Dönem'i boyunca da sürdürmüştür. Bölgede başta Zeus olmak üzere Apollon, Artemis, Tykhe ve Herakles gibi Yunan tanrılarının inancı yerleşik bir şekilde Hellenistik Dönem'in farklı evrelerinde varlığını ve yoğunluğunu göstermiştir. Buna göre bu yayında, Kapadokya Bölgesi’nde yarı ölümlü/yarı tanrı Herakles'in en erken verilerden itibaren başlayarak tapınımı ve kültünün yapısı, günümüze ulaşan verilere göre ele alınmıştır. Bu konu kapsamında çalışmada kullanılan temel kaynakları, bölgenin kentlerinde Herakles kültüne yönelik ortaya çıkan arkeolojik, epigrafik ve numizmatik veriler oluşturmaktadır. Buna göre bu yayının amacı, ortaya çıkan verilere göre Herakles inancının bölgede ne şekilde kabul gördüğünün ve yayılımının ortaya çıkarılmasıdır. Mevcut verilere göre yapılan değerlendirmede Kapadokya’da Herakles kültünün MÖ. 2. yüzyıl başlarından başladığı ve MS. 2. yüzyıla kadar varlığını sürdürdüğü anlaşılmaktadır. Buna ilaveten Herakles'in 
bölgede hem yarı tanrı/ölümlü hem de bir tanrı olmak üzere iki farklı tapınım gördüğü tespit edilmiştir. Yarı tanrı/ölümlü tapınımında Herakles aslında tanrısal bir kahramandır ve askeri eğitim alanların, atletlerin koruyucusudur. Bir tanrı olarak tapınımında ise kent koruyucu görevini üstlenmiştir.

Anahtar Kelimeler: Arkeoloji, Kapadokya, Herakles, Kült, Heykeltıraşılı.

\section{Giriş}

Kapadokya Bölgesi Alt Paleolitik Dönem'den itibaren başlayarak yerleşim görmeye başlamış (Yaman, 2019: 9 vd.), tarihin her dönemini yaşamış ve her daim önemini koruyan bir bölge olmuştur. Özellikle Hititlerden itibaren başlayarak siyasi, sanatsal ve dinsel açıdan hem Orta Anadolu'nun hem de çevresel etkilerin altında kalmıștır. Fakat bölge bu etkileșimi, kendi yerel yapısı ile kaynaştırarak daha muhafazakar ve sinkretik bir gelişmişlik gösterir. Bölgenin çevresel etkilere maruz kalmasında ise siyasi hakimiyetlerin yanı sıra farklı dönemlerde sınırlarının sürekli değişiklik göstermesi etkili olmuştur.

Kapadokya esasında kültürüne, köklerine oldukça bağlı bir yapı gösteren bir bölgedir. $\mathrm{Bu}$ nedenle Anadolu'nun diğer bölgelerine göre mevcut dinsel ve sosyal yapısına karşı oldukça tutucu bir tavır sergilemiş ve dolayısıyla dinsel değişimleri daha uzun zamanda gerçekleşmiştir. Bu tutuculuğun ise bölgenin Pers hakimiyetine girmesiyle beraber başladığı ve Roma İmparatorluk Dönemi sonlarına kadar sürdüğ̈̈ görülür. Özellikle Hellenistik Dönem'de Pers hakimiyetinden kaynaklı olarak yerleşen dini yapı bu dönemde de terkedilmemiş ve etkisini yoğun bir şekilde sürdürmüştür. Bundan dolayı Hellenistik Dönem sonlarında dahi Ahura Mazda, Mithra ve Anahitis'in bölgenin yaygın kültleri arasında olduğu anlaşılmaktadır (Hakman, 2015: 69 vd). Bölgede Yunan kültürü ve dini öğelerinin yaygınlaşması ise Kapadokya Kralı V. Ariarathes'in yoğun çabaları sonucu başlamıştır. Bu Hellenleşme sürecinde mevcut dini karakter sinkretik bir şekle bürünerek ortaya çıkmış ve gelişim göstermiştir.

Bölgenin Hititlerden itibaren süregelen en eski ve yerli kültünü dağ tanrı Argaios (Erciyes) oluşturmaktadır. Argaios bir dağ tanrı olarak hem Hellenistik Dönem'de hem de Roma İmparatorluk Dönemi'nde yoğun olarak tapınım görmüştür. Kapadokya'da tapınım gören Pers ve Yunan tanrıları ise çoğunlukla Argaios'un bünyesinde yer alarak kendini göstermiş ya da kabul ettirmiştir. Numizmatik veriler, agalma ve gemler üzerinde yer alan Argaios betimleriyle beraber görülen doğuya ve batıya ait simgeler bunun en önemli kanıtıdır. Bunların başında ise farklı epitetleriyle tapınım gören Zeus gelmektedir. Çoğunlukla Argaios Dağı zirvesinde yer alan tanrı bazı sikke ve gemlerde dağ zirvesinde farklı tanrılarla beraber yer alır (Baydur, 1994: 5 vd.). Bu sikke ve gemlerde figür/lerin dışında özellikle ay ve yıldız sembolleri kültün yapısını çözümlemek için bir ipucu niteliğindedir. Bu nedenle doğrudan atribülerinin olmayıșından dolayı kesin bir yargıya varılamasa da belirtilen sembollerden ve bölgedeki yoğun Doğu etkisinden dolayı Pers tanrıları olarak yorumlanmaktadır (Hakman, 2015: 76 vd.; 97 vd.). Bu inançların yanı sıra tapınak devleti Komana Kapadokya'da kökeni Hurri-Mitanni tanrıçası Šawuška'ya dayandırılan (Mutlu, 2016: 311) Anadolu'nun yerli tanrıçası Ma'nın birincil öneme sahip olduğu görülür.

Hellenistik Dönem ortalarında Yunan tanrı ve tanrıçalarına ait kültlerin Kapadokya'da çok daha fazla yaygınlaşmaya başladığı görülür. Başta Zeus olmak üzere Tykhe, Apollon ve Athena'nın da bölgede tapınım gördügü bilinmektedir. Bunlara ilaveten Kapadokya'da yaygın olarak tapınım gördüğü bilinen bir diğer kült ise arkeolojik, numizmatik ve epigrafik verilerde adı geçen ya da tasviri bulunan kahraman ve tanrı Herakles'tir. Buna göre bu yayın, mevcut buluntular yoluyla bölgenin dini yapısına önemli katkılar sağlayacak; Herakles'in bir kahramandan fazlası olduğunu, onun bölgede bir tanrı mertebesinde tapınım gördüğü yerleşik kült yapısını açığa çıkaracaktır. 


\section{Herakles'in Dini Karakteri ve Tipolojisi}

Yunan sanatında sıkça tasvirleriyle karşılaşılan Herakles, oldukça farklı ve değişken bir kişiliğe sahip görülse de aslında mitolojide trajik bir tanrısal kahramandır. Yunan ve Roma tragedyası sıklıkla onun bu yapısını kullanmayı tercih etmiştir. Bu trajedinin nedeni Herakles'in, Hera'nın öfkesi nedeniyle geçirdiği cinnetle ailesini katletmesidir. Bu cinnetin ardından ona verilen on iki iş, Herakles'in ruhunu ve vicdanını hafifleteceği görevlerdir. Bu nedenle de en çok bilinen ve sanatta en çok tercih edilen onun bu işleri olmuştur. Bu işlerinde ya da farklı mitoslarında Herakles koruyucu bir kahraman, cinnet getiren bir koca, ideal yönetici, sarhoş bir eğlence düşkünü ya da kadın klyafetleri içerisinde bir erkek (Pache, 2010: 398) olarak karşımıza çıkar.

Vazolar üzerinde, mezar kabartmalarında, mimariye bağlı ya da bağımsız heykeltıraşlıkta özellikle Hellenistik Dönem'den itibaren, sıklıkla Herakles'in ve mitoslarının yer aldığı görülür. Herakles en yalın tasvirlerinde elinde lobutu ile betimlenmiştir. Herakles'in tasvirlerinde lobutla beraber çoğunlukla aslan postu ve Hesperidler'in altın elmalarının birlikte kullanıldığı görülür. Vazo betimlerinde ve kabartmalarda on iki işini ve onun dışında dahil olduğu mitosları ile görülen Herakles'in bağımsız heykellerinde ise üç farklı tipi ile karşılaşılır. Ayakta dururken, otururken ya da elinde bir kadeh ile uzanmış bir şekilde tasvir edilen Herakles'in bu tiplerinde de yine belirtilen atribüleri bulunmaktadır.

Oturan Herakles'i ilk defa Büyük İskender'in isteği üzerine Lysippos yapmıştır (Murray, 1882: 240-243; Bartman, 1992: 151-152). Büyük İskender, symposiumunda ona eşlik edecek olan bir kahraman tanrı yaptırmak istemiş, kendine bir tanrı sofrası kurdurmuştur. Bu eser hakkında, hicivleriyle bilinen Romalı Martialis ve lirik ve epik şiirleriyle bilinen Statius mısralarında bilgi vermektedir. İki şairin de birbirlerini doğrulayan anlatımlarına göre oturan Herakles eseri, Büyük İskender'den sonra Hannibal ve daha sonra Sulla'nın eline geçmiştir. Son olarak Romalı Novius Vindex'in koleksiyonunda yer alan bu eser bir Roma ayağ 1 ölçüsündedir ${ }^{1}$ (Martialis, Epig. 9.43-44; Statius, Silvae 4.6.32-47). Bronzdan yapılan bu eserde Herakles, Epitrapezios epitetiyle bilinir. Epitetin masada, masanın üzerinde anlamına gelen bu kullanımı eserin tipolojisini de anlatır: Herakles bir masada otururken elinde şarap kadehi ile tasvir edilmiştir. Büyük İskender' in bu eseri yaptırmasındaki asıl amaç köklerini dayandırdığı Herakles'ten tanrısal gücü aldığını göstermek olmalıdır ${ }^{2}$. Bu tiple ilgili bilinen önemli örnekler kolosal boyutlarda olan Alba Fucens heykeli (Pollit, 1986: 52) ve Konya'da bulunan Savatra heykelciğidir (Doksanaltı, 2016: 473). Ayrica bu tipin kopyalarının Roma İmparatorluk Dönemi'nde yapıldığı bilinmektedir.

Oturan Herakles tipinin bir başka çeşitlemesini Herakles Invictus olarak bilinen heykeltıraşlık örnekleri oluşturmaktadır. Invictus tipinde Herakles, ordunun koruyucu kahraman tanrıdır ve askerin yenilmezliğini sağlar. Roma'da yaygın olarak bilinen bu tipin önemli örnekleri arasında Palazzo Altemps'te bulunan Herakles heykeli yer alır. Oturan Herakles'in Invictus tipi ayrıca sikkeler üzerinde, yüzüktaşlarında ya da madalyonlar üzerinde de tercih edilmiştir. Bu tipte Herakles doğal bir kaya üzerine serdiği aslan postu üzerinde otururken, sağ elinde altın elmaları, sol

\footnotetext{
${ }^{1}$ Eserin boyu ile ilgili Statius tarafından verilen bu yazınsal kaynaktaki bilgi, araştırmacılar tarafından oldukça tartışmalı bulunmuştur. Tartışmanın merkezinde Herakles' in bir sofrada yer alan küęük bir eserde kendini göstermesidir. Dolayısıyla eserin küçük boyu, hem dönemin en önemli eserlerine ve sanatına yön veren Lysippos ve soyunu Herakles'e dayandıran Büyük İskender için hem de dini açıdan o zamanlarda dahi uygun görülmeyecektir. Dolayısıyla bu bilgi, heykelin boyundan bahseden yazınsal kaynağın bir hatası olarak da yorumlanabilmektedir. Şayet boyu gerçekten bir Roma ayağı kadar ise bu esere yüklenen anlamların boşa çıkacağı düşünülmektedir. Yani bu görüşe göre Büyük İskender sofrasına sadece oturan Herakles şeklinde bir süs eşyası koymuş olacaktır (Bu konu hakkında tartışma için bkz. Bartman, 1992: 151; Murray, 1882: 243.). Bu tartışma içinde bu yorumlar makul gibi görülse de bu tipin gerçek ve kolosal boyutlarda kopyalarının yapılması düşündürücüdür ve heykelciğin bundan daha fazla bir anlam taşıması olasıdır.

${ }^{2}$ Büyük İskender'in bu heykelciği yaptırmasındaki temel sebep, tartışmasız bir şekilde Herakles'in tanrısal gücü ve köklerini ona dayandırmasıdır. Fakat böyle güçlü ve tanrısal bir nedene rağmen Büyük İskender'in neden bu denli küçük bir eser yaptırdığı belirsizdir ve tartışmalıdır. Bu nedenle Lysippos eserin heykelcik dışında normal ölçülerde bir benzerini daha yapmış olmalıdır.
} 
elinde lobutunu tutarken betimlenmiştir. Buna ilaveten özellikle sikkeler üzerinde Herakles'in ileri doğru uzattığı elinde Nike ile betimlendiği de görülür. (Palagia, 1990: 59-60, 64, fig. 12-16). Elbette oturan Herakles tipi sadece bu eserlerle sinırlı değildir. Ashmolean Museum'da bulunan ve EA1999.31 envanter numaralı Baktria'dan gelme Herakles, doğal bir kaya üzerinde otururken sağ eliyle tuttuğu lobutuna dayanmış ve yarı uzanmış bir şekilde dinlenirken görülür. Sol bacağı üzerine ise aslan postu yerleştirilmiştir (Ashmolean, t.y.).

Ayakta duran Herakles tipinde ise en tanıdık pozu, bir elinde gürzü olan lobutu diğer elinde aslan postunun olduğu eserlerdir. Bu tipte sakalsız genç bir adam olarak betimlenen ölümlü tanrı, Herakles Fulgor olarak da bilinir. Bu tipin tasvirlerinde genel olarak Herakles sağ eliyle lobutunu tutarken, sol kolundan aşağıya doğru aslan postu sarkmaktadır. Sakalsız ve genç olarak betimlenen bu tipin en bilindik örneği $193.5 \mathrm{~cm}$ boyuyla kolosal ölçülerde yapılmış Lansdowne Herakles’idir. Getty Museum'da bulunan bu eser, Roma İmparatoru Hadrianus'un Tivoli'deki villasinda bulunmuştur. MS. 125 yılına tarihlendirilen eserin orijinalinin MÖ. 4. yüzyılda yapılmış olduğu düşünülür (Getty Museum, t.y.; Howard, 1978). Herakles, bu tipinde çıplak bir şekilde ayakta dururken, sağ elinde, ilk işinde öldürdügü Nemea aslanının postunu tutarken, diğer elinde omuzuna dayayarak tuttuğu lobutu bulunmaktadır. Ayakta duran ve dinlenen Herakles'in bir başka tipinde olgun yaşlarda ve sakallı olduğu görülür. Erken dönem tasvirleri, genç ve sakalsız olarak tercih edilen ayakta duran Herakles tipi, daha sonradan sakallı ve olgun yaşlarda yapılmaya başlanmıştır (Işın, 2007: 65). Bu tip yaygın ve popüler olarak Yorgun Herakles ya da Herakles Farnese olarak bilinir. Herakles'in elinde, son işine gönderme yapılan Hesperidler' in altın elmaları bulunur. Ayakta duran Herakles'in bu farklı tiplerinde temel tipolojik nokta, onun dinlendiği anda betimlenmesidir.

Farklı tiplerde kült heykelleri yapılan Herakles ${ }^{3}$ esasında Perseus, Theseus ya da Akhilleus gibi bir ölümlünün ölümsüz ile birleşmesinin neticesinde ortaya çıkmış tanrısal bir kahraman ya da kahraman bir tanrıdır. Herakles tüm işlerinin ve mitoslarının ardından kendini gerçekleştirmiş ölümlü, kahraman bir tanrıdır. Bu nedenle de eski çağda kültü, çoğu zaman tanrı seviyesine çıkarılarak oldukça geniş alanlara yayılmıştı ${ }^{4}$. Yunan anakarasında, adalarında ${ }^{5}$, Anadolu'da ve Roma'da sporcuların, askeri eğitim alanların, askerlerin ya da kentlerin koruyucu tanrısı olarak yaygın bir şekilde tapınılmıştır. Sporcuların koruyucu tanrısı olması sebebiyle gymnasionlarda düzenlenen müsabakalar da Herakles onuruna düzenlenmiştir. Baş tanrı Zeus ile ölümlü Alkmene'nin oğlu olan Herakles'in Yunan ve Roma kültlerindeki bu tanrısal ya da kahramansal yapısı esasında tartışmalıdır (Stafford, 2010: 228-44). Herakles kahraman, yarı tanrı-yarı ölümlü, tanrı gibi nitelendirmelerle farklı dinsel statülere yerleştirilir ki bunun nedeni kültünün bir tanrı seviyesinde yaygınlaşmış olmasından kaynaklıdır. Mitolojik hikayesinde her ne kadar yarı tanrı/ölümlü olsa da, yaşlanan ve nihayetinde ölen bir karakter olan Herakles -Zeus ile olan bağı koparılmadan bir tanrı olarak da tapınım görmüştür.

Eski çağ şair ve yazarları Herakles'in dinsel karakterine, özellikle de bir tanrı olarak nasıl algılandığına açıklama getirmişlerdir. MÖ. 5. yüzyılın şairi Pindaros'a göre (Nemean 3.22) Herakles, öldükten sonra heros theos olarak tapınım görmüştür. Pausanias 4.32.1'de gymnasionlarda ve güreş müsabakalarında (Hermes ve Theseus ile birlikte) Herakles' in onurlandırıldığından bahseder. Ayrıca Herodotos, 2.44'te Herakles için heros kai theos ifadesini kullanarak onun hem tanrı oluşunu hem

\footnotetext{
${ }^{3}$ Her ne kadar dilbilimciler etimolojisi hakkındaki görüşü kabul etmese de, Yunanlılar Herakles adının anlamını Hera'nın şanı ya da Hera'dan gelen şan olarak açıklamaktadırlar (Pache, 2010: 398).

${ }^{4}$ Atina National Archaeological Museum'da bulunan, 12126 envanter numaralı adak kabartması üzerinde ayakta duran Herakles'in ayaklarına kapanmış bir şekilde, tapınır görüntüde bir figür betimlenmiştir (Salta, 2019: 81). Olympieion'un güney teras duvarında bulunan bu kabartma, Herakles'in bir tanrı olarak tapınım gördüğünün kesin kanıtları arasında yer alır. Bu kabartmada sakallı ve çıplak olarak betimlenen Herakles, aslan postu ve lobutunun yanı sıra bereket boynuzu tutmaktadır. Bu onun bereketi temsil eden bir epitetle tapınım görmüş olabileceğini gösterir.

${ }^{5}$ Kyklad Adaları'ndan Thasos'ta Herakles bir tanrı ve bir kahraman olmak üzere iki ayrı tapınım görmüştür (Pache, 2010: 404 vd.).
}

www.turkishstudies.net/social 
de kahramanlığını vurgulamış ve kültüne açıklık getirmiştir. Yunan'da başlayan bu kahraman tanrı geleneği özellikle Hellenistik Dönem'den itibaren oldukça hızlı bir şekilde yayılmış ve yerleşik bir tanrı olarak kabul görmüş̧ür. Kültünün geniş alanlara yayıldığı Anadolu'da İonia, Lydia, Kapadokya ve Phyrgia'da Herakles'in aynı şekilde koruyucu tanrı sıfatıyla tapınım gördüğü bilinir.

Herakles'in tapınım gören bu ölümlü halinden yola çıkarak Yunan ve Roma'da yöneticiler ya da devlet adamları soylarını Herakles'e dayandırmış ya da başlarında aslan postuyla betimlenerek ona öykünmüşlerdir. Büyük İskender ${ }^{6}$, VI. Mihridates, Commodus gibi devlet adamları portrelerinde Herakles gibi betimlenerek tanrısallıklarını ordusuna, halkına ve düşmanlarına karşı göstermek istemişlerdir ${ }^{7}$. Roma'da Capitoline Museum'da bulunan ve MS. 2. yüzylla tarihlendirilen Commodus büstünde imparator, başında aslan postu, sağ elinde omuzuna dayadığı lobutu ve ileriye doğru uzattığ1 sol elinde Hesperidler'in altın elmalarını tutmaktadır (Musei Capitolini, t.y.). Portrede imparatorun Herakles'in atribüleriyle donatılması Commodus'un Imparator Herakles görüntüsüne ulaşmasını sağlamıştır. Sikkelerinde de aslan postuyla betimlendiği görülen imparatorun bu portreyi yaptırmasındaki amacı, ölen tanrısal kahraman Herakles'in epiphanisini kendi benliğinde gerçekleştirmek istemesi olmalıdır.

Louvre Museum'da bulunan bir portrede Pontus Kralı VI. Mithridates, başında aslan postuyla tanrısal Herakles görüntüsünde tasvir edilmiştir (Erciyas, 2006: 148-149). Roma'y1 tarihinde askeri açıdan en çok zorlayanlar arasında olan VI. Mihridates'in başına yerleştirilmiş olan aslan postunda dikkati çeken, hayvanın iki dişinin kralın alnına yerleştirilmesidir. Bu da aslında kralın saldırgan ve yenilmez tutumunu ifade etmektedir. Esasında VI. Mithridates, Herakles görüntüsüyle özellikle siyasi ve askeri olarak gücünü, yenilmezliğini göstermek ve düşmana gözdağ 1 vermek istemiştir. Bu ve benzeri örneklerin sebebi, Herakles'in ölen bir tanrı olarak görülmesi sebebiyle kral ya da imparatorların da kendilerini aynı tanrısal kurguya yerleştirmeleridir. Bu güçlü nedenden dolayı da Herakles, ona biçilen yarı ölümlü yapıdan çıkarılarak bir tanrı gibi tapınım görmüştür. Kültün bu yapısı ile Yunan, Roma ve Anadolu'da benzer şekillerde uygulamalarla karşılaşılmaktadır. Yunan'da ortaya çıkan bu inancın Anadolu'da yayılım gösterdiği önemli bölgelerden biri de Kapadokya Bölgesi olmuştur.

\section{Kapadokya'da Herakles Kültü}

Bölgede Herakles kültünün varlığı arkeolojik, epigrafik ve numizmatik veriler sayesinde tespit edilmiştir. Buna göre mevcut verilerin çeşitliliği ve süreklilik göstermesi bölgede yerleşik bir kültün karakterine işaret etmektedir. Kültün yapısı, farklı dönemlerdeki tapınım şekli ve yayılımı bölgede ortaya çıkan eserler sayesinde açığa çıkmıştır.

\section{Heykeltıraşlık Eserleri}

\section{Tepebağları Heykelciği}

Bölgede Herakles kültünün önemli kanıtlarından biri, Niğde Arkeoloji Müzesi’nde bulunan 13.40.73 envanter numaralı bronz heykelciktir. Bu heykelcik, 1973 yılında Prof. Dr. Nimet Özgüç başkanlığında yapılan Tepebağları kazısında ${ }^{8}$, höyügün II. yapı katında XVI no'lu odada bulunmuştur (Levha 1). T. Anlağan tarafindan yayınlanan bu heykelciğin kimliği konusunda kesin

\footnotetext{
${ }^{6}$ Büyük İskender'in ataları ile ilgili en eski kaynak Herodotos'tur. Herodotos'a (8. 137) göre Herakles'in yedinci kuşak atası Perdikkas'tır. Buna göre efsanevi Perdikkas'ın atası ise Herakles'in soyundan gelen Temenoslu Argos' tur. Bu nedenle anne tarafından Akhilleus'un, baba tarafından Herakles'in soyundan gelen Büyük İskender'in kendini tanrısal bir yere koyması olağandır.

${ }^{7}$ Herakles'in lobutu ve özellikle de aslan postu ile yerleşik tipolojisi, Yunan ve Roma İmparatorluk Dönemi'nde oldukça fazla tercih edilmiştir. Ayrıca bu tipoloji ile Herakles Suriye, Hindistan, Afganistan'a kadar yayılım göstermiştir (Hsing ve Crowell, 2005).

${ }^{8}$ Heykelciğin buluntu yeri olan Tepebağları Höyüğü, Niğde İli’nin 4 km batısında bulunan Fertek/Aydınyurt Köyü’nün güneydoğusunda yer almaktadır. Neolitik Çağ sonundan itibaren buluntu veren Tepebağları Höyüğ̈̈ kazılarında, Kazı Başkanı Prof. Dr. Nimet Özgüç, Hellenistik Dönem ve Ortaçağ tabakalarında yoğunlaşmıştır.
} 
bir yargıya varılmamıştır (Anlağan, 1972: 113). Anlağan, heykelciğin başının olmayışından ve tipolojik özelliklerindeki benzerliklerden dolayı Hermes ya da Herakles olabileceği öne sürmüş; buna rağmen tasvir tarzına göre daha çok Herakles olma ihtimali üzerinde durmuştur?.

Tepebağları heykelciği, $9.4 \mathrm{~cm}$ yüksekliğinde, omuz ve kalça kısmından 3.7 ve $3.6 \mathrm{~cm}$ genişliğindedir. Başı, sağ kolu bileğin üst tarafından, bacakları bileğin üst kısmından kırılmıştır. Ayakta duran heykelcikte ağırlığı sol bacak taşımakta, sağ bacak ise hafif dizden kırılmış ve öne doğru atılmıştır. Sağ kolu aşağıya ve hafif öne doğru uzatılarak bırakılmıştır. Ağırlığı taşıyan sol bacağın ve kolların bu tasviri, yere dayadığı bir nesneyi tutmuş olabileceği izlenimini doğurur. Bu nedenle ilk olarak akla Herakles'in lobutu gelmektedir. Sol omuzuna attığı ve gögüs üzerinden getirerek kolu üzerine doladığı aslan postu aşağıya doğru sarkmaktadır. Postta aslanın başı net olarak anlaşılmaktaysa da yüzün detayları belirgin değildir. Ayrıca ileri doğru uzattığı sol elinde bir elma tutmaktadır. Heykelciğin vücudu alışagelmiş iri ve kaslı Herakles görüntüsünün dışındadır; fakat kolları, gögüs hattı ve bacakları hafif kaslı olarak verilmiştir. Özellikle hafif göbekli betimlenmesi rahatlamış ve gevşemiş bir görüntü ortaya çıkarmıştır. Kontrapost hareketine uygun olarak dizden kırılan bacak ile ağırlığı taşıyan bacak aynı aksta değildir. Bunu heykelciğin arka tarafinda özellikle kalçada görmekteyiz. Omuzuna attığı postun devamı, heykelciğin arka tarafında, kürek kemiğine gelecek şekilde yerleştirilmiştir. Heykelciğe profilden bakıldığında omuz geçişinde, postun sırta atıldığ belirgin bir şekilde görülmektedir. Ancak bu geçişte postun oldukça inceltilerek bedenine yapışmış bir görüntüde olduğu anlaşılmaktadır. Bu tipolojik özellikleriyle dinlenen Herakles ikonografisine ${ }^{10}$ uymaktadır. Heykelciğin genel tipolojisi, -şayet sol kolunda yer alan aslan postu olmasaydı Hermes tipolojisi ile de uyumludur. Fakat kolundan sarkan aslan postunun şüpheye yer bırakmayacak şekilde belirgin olması ve elinde tanrısal kahramanın son işi Hesperidler'in altın elmasının bulunması Herakles olduğunun açık bir kanıtıdır ${ }^{11}$.

Hellenistik Dönem'den itibaren sıklıkla karşılaşılan ve Roma İmparatorluk Dönemi'nde yoğun olarak yapıldığı bilinen dinlenen Herakles heykelcikleri, Anadolu'da da yoğun buluntu vermiştir. Bunlar arasında Teğebağları heykelciği ile benzer ya da yakın tipolojik özellikler taşıyan çok sayıda heykelcik mevcuttur. Yerel ve bölgesel farkl1lıklardan dolayı elbette birebir benzerliğin olması bu anlamda beklenmemelidir. Esasında Kapadokya Bölgesi'nin özellikle inanç ve heykeltıraşlıkta Doğu-Batı etkileşimli sinkretik karakterini, kendine özgü biçimde yansıtmasının tarihsel süreçte süreklilik gösterdiği bilinmektedir. $\mathrm{Bu}$ nedenle Anadolu'da bulunan benzer örneklerle karşılaştırıldığında özellikle sol koluna aslan postunu dolama şekli bölgeye özgü yerel bir yorumlama olmalidir.

Tepebağları heykelciği ile hem tarihlendirme hem de Herakles olduğunun kanıtlanması amacıyla benzer özellikler taşıyan genç ya da olgun yaşlarında betimlendiği görülen çok sayıda heykeltıraşlık örneği bulunmaktadır. Konya, Silifke, Denizli ve Antalya'da bulunan bronz Herakles heykelcikleri ile karşılaştırıldığında, lobut tutan sol kolun ve aşağıya doğru aslan postunun sarktığı sağ kolun genel tipolojik özelliklerinin benzer olduğu görülür (K1zgut, 2004: 306-322; Getty Museum, t.y.). Ancak Tepebağları Heraklesi’nde aslan postunun dar hacimli oluşu, baş kısmı dışında

\footnotetext{
${ }^{9}$ Esasında bu heykelcik, Hermes ile benzerlik kurulmaya çalışıldığında Hermes'e; bir Silen ile benzerlik kurulmaya çalışıldığında Silen'e benzetilebilir. Fakat Herakles ile beraber üç mitolojik karakterin genel tipolojik karakterleri ve atribüleri dikkatlice değerlendirildiğinde, bu heykelciğin Herakles olduğu aşikardır.

${ }^{10} \mathrm{Bu}$ heykelcik için dinlenen Herakles ifadesi, Herakles Fulgor tipi ile eş anlamlı olarak kullanılmıştır. Burada Herakles’in yorgun olarak tanımlanmayışının nedeni eserin genç bir vücuda sahip olmasıdır. Yorgun Herakles tipinde ise dinlenen Herakles'in sakallı ve olgun-ileri yaşlarda bir vücuda sahip olduğu görülür.

${ }^{11}$ Isparta Müzesi'nde bulunan iki bronz heykelcik (kat. no. 2 ve 3) (Fırat, 2015: 11) ile karşılaştırıldığında Tepebağları heykelciği, özellikle karın kısmı, vücudun rahatlamış duruşuna uygun olarak benzerlik göstermektedir. Bu durum, heykelciğin Hermes olarak algılanmasına sebep olsa da Tepebağları heykelciğindeki mevcut atribülerin anlaşlır bir şekilde Herakles'e ait olduğu görülmektedir. Bu nedenle heykelcikler üzerindeki bu benzerlik dönemin benzer sanatsal uygulaması şeklinde açıklanabilir. Ayrıca Herakles ve Hermes tipolojisinin, Anadolu müzelerinde yer alan heykelcikler ile karş1laştırması için bkz. Kızgut, 2004: 56-126; 306-322.
} 
postun detaylarının olmayışı ve zarif bir biçimde aşağıya doğru bırakılması, bölgeye özgü yerel bir sanatsal uygulama olmalıdır. Diğer taraftan elinde tuttuğu elmayı ileri doğru uzatması yine özellikle Anadolu'daki bronz ya da terrakota heykelciklerde rahatlıkla görülebilir (Frrat, 2015: 189, 193). Bunların yanı sıra dinlenen görüntüsünde vücudun gevşemiş, rahatlamış oluşu, (hafif) kontrapost hareketi de yine Anadolu örnekleriyle benzerdir.

Anadolu'da, dinlenen/yorgun Herakles ikonografisinde Tepebağları heykelciği ile benzer tipolojik özellikler taşıyan kabartmalar da mevcuttur. Burdur Keçili Steli ve Halı Kaya Herakles Kabartmas1 $^{12}$ kolların duruşu ve vücudun rahat tasviri ile Tepebağları heykelciği ile benzerdir. Özellikle Keçili Steli’nde aslanın baş kısmı ile benzerlik oldukça fazladır (Metin, 2016: 1140).

Anadolu dışında da yine tipolojik olarak benzerlik kurulabilecek çok sayıda Herakles heykelciği bulunmaktadır. Ashmolean Museum'da, Tepebağları heykelciğinin kollarının mevcut durumu (sağ kol açıklığı, sol kol üzerindeki aslan postu) ile benzer özellikler taşıyan EA1993.34 envanter numaralı bronz bir Herakles heykelciğinin sağ elinde lobut, sol elinde aslan postu yer almaktadır. Baktria'da bulunmuş bu heykelcik MÖ. 2. yüzyıla tarihlendirilmektedir (Ashmolean, t.y.) ${ }^{13}$. Yine aynı müzede EA1993.33 envanter numaralı bronz Herakles heykelciği (Ashmolean, t.y.) kolların duruşu ile benzer tipolojik özellikler taşımaktadır. MÖ. 1. yüzyıl ile MS. 1 yüzyıl aralığına tarihlendirilen bu eser vücudun rahatlamış, dinlenen formuna Tepebağları heykelciği ile daha benzer özellikler taşımaktadır. Buna göre Tepebağları heykelciği, mevcut tipolojik özelliklerine göre Hellenistik Dönem sonu-Erken Roma Dönemi başlarına tarihlendirilmektedir.

Tepebağları heykelciğinde görülen dinlenen Herakles pozu tanrısal kahramanın en çok tercih edilen tasvirleri arasında yer alır. Fakat budaklı ya da budaksız lobutu, aslan postu ya da elmalariyla betimlenen dinlenen Herakles'in bu atribülerine göre adlandırılmasının yapılması daha yerinde bir tanımlama olacaktır. Bu nedenle elinde elma ile betimlenen Herakles örneklerinin İ. Kızgut tarafından Hesperidler'in Herakles'i olarak tanımlanması nedeniyle (Kızgut, 2004: 311), Tepebağları heykelciği de bu isimlendirmeye dahil edilmelidir. Buna göre bahsedilen ve karşılaştırma yapılan eserlerin özelliklerine göre Tepebağları heykelciğinin Hesperidler'in genç Herakles' ini tasvir ettiği anlaşılmaktadır.

\section{Tyana Herakles Heykeli (Parçası)}

Tyana, imparatorluk döneminde özellikle kamu binalarıyla Roma'nın gelişmiş bir kenti konumunda olmuştur. Kentin tiyatro, gymnasion, palaestra gibi yapılarında ve tapınaklarında Zeus, Herakles, Athena, Mithra, Astarte gibi tanrılara adaklar yapıldığı, yapıların tanrılarla kutsandığı bilinmektedir. Tyana'da tapınım gören tanrılardan biri olan Herakles ise Roma İmparatorluk Dönemi'nde kent tanrısı konumunda olmuştur (Berges-Nolle, 2000: 34). Ancak Herakles kültünün ortaya çıkış sürecinin en erken izlerine kentte Hellenistik Dönem'den itibaren rastlanmaktadır. Bu dönemde Yunan geleneğine uygun olarak, gymnasionlarda Herakles (ve onunla birlikte Hermes) adına agonlar düzenlenmiş ve adaklar sunulmuştur (Berges ve Nollé, 2000: 286, 204-205). Dolayısıyla Hellenistik Dönemde Tyana'da atletlerin ve askerlerin koruyucu tanrısı olan Herakles, Roma İmparatorluk Dönemi’nde kentin koruyucu tanrısı olarak tapınım görmüştür.

Tyana'da bu kült ile ilgili epigrafik ve numizmatik verilerin yanı sıra Herakles'e ait bir heykel parçası bulunmuştur (Levha 2). Dikdörtgen bir kaide üzerine yerleştirilen bu Herakles heykeli günümüze sağlam ulaşmamıştır. Niğde Arkeoloji Müzesi'nde 3.4.82 envanter numarasıyla bulunan

\footnotetext{
${ }^{12}$ Bu kabartma, Burdur İli Aşağımüslimler Köyü Zeynepbelen Mevkii’nin güneydoğusunda doğal kaya üzerinde yer alır. Prof. Dr. Mehmet Özsait tarafından tespit edilen bu kabartmanın sağında, dört satırdan oluşan Yunanca bir yazıt bulunmaktadır (Özsait ve Özsait, 2011: 46).

${ }^{13}$ Baktria Herakles heykelciği iri, kaslı ve dolgun bir vücuda sahip bir şekilde betimlenmiştir. Tepebağları heykelciğinin aksine aslan postu, boyundan bağlanarak kol üzerine getirilmiştir. Fakat burada benzerliğin kurulması sadece kolların duruşuna bağlı olarak Tepebağları heykelciğinin tarihlendirmesine yardımcı olması dışında, Herakles olduğunun da kanıtlanması amacinı gütmektedir.
} 
heykelin sağ ayağı ve $47 \mathrm{~cm}$ olan sol bacağı sağlamdır. Geride bulunan sağ ayağın hafif sağa doğru yönelerek duruşu, ağırlığı bu ayağın taşıdığını gösterir. Sol bacak ise gergin bir şekilde yana ve döndürülerek betimlenmiştir. Bacağın üst kısmından itibaren döndürülmeye başlayan bacak, ayak kısmına gelindiğinde neredeyse profilden bir görüntüye ulaşmıştır. Bu hareketin zorluğu neticesinde iri ve kaslı bacağın gergin görüntüsü öne çıkmaktadır. Özellikle diz kapağından kaval kemiğine geçiş, bu döndürülme nedeniyle anatomik olarak uygun görülmemektedir. Sol bacağa bitişik olarak Nemea Aslanı'nın dolgun kürkü yapılmıştır. Bu kürk, bir boğa başı üzerine yerleştirilmiştir. Lobutu ise boğa başı üzerine desteklenmiştir. Özellikle profilden bakıldığında Herakles'in iri ve kaslı sol kolunun altına, aslanın başı üzerinde yer alan post kısmı yerleştirilmiştir. Aslanın başını ise Herakles'in parmaklarıyla kavramış olduğu görülür. Bu tipolojik özellikleri ile heykel (parçası), MS. 2. yüzyılın 2. yarısına tarihlendirilmektedir (Berges-Nolle, 2000: 111).

$\mathrm{Bu}$ heykel parçasında dikkati çeken, lobuta destek olarak yapılan boğa başıdır. Herakles heykellerinde destek olarak kullanılan boğa başı, MS. 2-3. yüzyıla tarihlendirilen Hope Herakles'inde de yer almaktadır. Orijinali MÖ. 370-350 yıllarına tarihlendirilen ve Skopas'a ait olduğu düşünülen Roma kopyası bu heykelde (Palagia, 1984: 107), Herakles'in sağ elinde tuttuğu lobutunun altına destek olarak boğa başı yerleştirilmiştir. Boğa başının destek olarak kullanıldığı bir başka eser ise Perge kazılarında ortaya çıarılan ve Antalya Arkeoloji Müzesi'nde bulunan yorgun Herakles heykelidir (Ekinci vd., 2012). MS. 2. yüzyıla tarihlendirilen heykelde, boğa başı yine dinlenen Herakles'in bu duruşuna taban desteği olarak yapılmıştır. Aslında bu eserlerde kullanılan boğa başının Herakles'in Farnase Boğası görevine bir gönderme olduğu düşünülebilir. Fakat muhtemelen bu mitolojik detay göz önüne alınarak, Herakles'in lobutunun altına bir kaya parçası yerleştirmek yerine dekoratif amaçlı boğa başı kullanılmıştır. Esasında bu uygulama Klasik Dönem Herakles tiplerinin Roma kopyalarında daha çok görülmektedir. Ayrıca boğa başı şeklindeki destekler, farklı tanrılara ait heykeltıraşlık eserlerinde de sıklıkla tercih edilmiştir. Çoğunlukla da bunun esas nedeninin tanrıya boğa kurban edilmesiyle ilgili olduğu düşünülmektedir (Palagia, 1984: 107).

\section{Kayseri Herakles Lahti}

1991 yılında Kayseri'de bir temel kazısı sırasında bulunan Herakles Lahdi, bölgede Herakles inancının varlığına yönelik önemli bir eserdir. Kayseri Arkeoloji Müzesi'nde bulunan 92/1 envanter numaralı bu eser, Pamhylia tipi frizli bir lahittir ${ }^{14}$. Herakles'in 12 işinin anlatıldığı mermer lahit, semerdam çatılıdır. Tepe ve köşe akroterlerinde palmet ve antefikslerinde aslan başı tercih edilmiştir (Cirt1l ve Altuncan, 1993: 27).

Lahdin dar yüzünde merkezde bir kapı, kapının her iki yanında lahdin koruyucusu görevinde iki erkek figürü betimlenmiştir. Solda yer alan figür sivri başlığı, uzun kollu kıyafeti ile bir köle/hizmetkar görüntüsündedir. Her iki figürün duruşunda farklılıklar olsa da kıyafetleri aynıdır. Yer altı dünyasına giden kapının bekçileri olarak görülen bu figürler herhangi bir matem görüntüsü içinde değillerdir. Bu durum onların mezar sahibi ile herhangi bir yakınlıkları olmadığını gösterir. Dolayısıyla sadece mezarı korumakla görevli iki figür, bu kapının her iki yanına yerleştirilmiştir. Ayrıca baş kısmı sağlam olan soldaki figürün başında Frig başlığı bulunması, kıyafetlerinin uzun kollu ve paçalı olması, onların mezar sahibinin hizmetinde olduğunu göstermektedir.

Lahdin diğer dar ve iki uzun yüzünde ise Herakles'in 12 işi betimlenmiştir. Herakles'in Nemea Aslanı ile başlayan işleri Hesperidler'in altın elmalarının getirilmesi ile bitmektedir. Her işinde Herakles figürü tekrarlanarak lahtin etrafı kahraman tanrı ile donatılmıştır. İşlerinin ilerleyişinde Herakles'in her seferinde yaş alarak ve son işinde yorgun, yaşlı bir biçimde betimlenmesi oldukça etkileyici bir kronolojik ilerlemedir. İlk işi Nemea Aslanı'nda genç ve sakalsız

\footnotetext{
${ }^{14}$ Uzunluk x Genişlik x Yükseklik: 215x101x133 cm. Tekne Yüksekliği: $90 \mathrm{~cm}$. Kapak Yüksekliği: $43 \mathrm{~cm}$. (Cirtıl ve Altuncan, 1993: 27).
}

www.turkishstudies.net/social 
betimlenen Herakles, son işinde sakallı, kırışık ve kalın derili yüzünün yanı sıra kaslı vücudu ile de yorgun betimlenmiştir. Bu son sahnede Hesperidler'in altın elmalarının getirilmesi işiyle ilgili, mitosuna uygun hareketli bir sahne tercih edilmemiştir. Heykeltıraş, lahdi çevreleyen işlerin sonuna gelindiğini gösteren bir yorumla, bu sahneyi yorgun Herakles tipinde ifade etmek istemiştir. Diğer işlerindeki hareketliliğin son bulduğu, etkileyici bir durgunluk ile işlerinin bitirilmesi ustacadır. Ayrıca bağımsız heykellerde sıklıkla betimlenen yorgun Herakles tipinin burada hangi işine gönderme yaptığı konusunda bir karışıklık olmayacağ için bu tasvir tarzı bilinçli bir tercihtir.

Herakles Nemea Aslanı, Hydria'nın öldürülmesi ve Eurymanthos yaban domuzunun öldürülme işlerinde genç ve sakalsız olarak betimlenmiştir. Keryneia Geyiği' nin yakalanması işinden itibaren ise sakallı olarak betimlenmeye başlanır. Ancak bu işinde sakalları, çene hizasında hafif çıkmaya başlamış olarak görülür. Stymphalos kuşlarının yakalanması sahnesinde sakalları öncekine göre biraz daha gürleştirilerek betimlenmiştir. Augias'ın ahırlarının temizlenmesi işinden itibaren ise tamamen gür sakallı ve olgun yaşlarında bir erkek olarak betimlenmeye başlanır. Son işinde yüz ve vücut yapısının diğer on bir Herakles içinde en olgunu olduğu görülür. Tüm işlerinde çıplak olarak görülen Herakles'in elinde budaklı lobutu ve kolunda ya da boynuna bir pelerin gibi bağladığı aslan postu bulunmaktadır. Sadece Stymphalos kuşlarının yakalanma sahnesinde sol kolundan aslan postu aşağıya doğru sarkmaktadır. Ayrıca bu işinde iki eliyle yaya taktığı okunu germek üzereyken betimlenen Herakles'in sırtında yer alan sadağın kayışı gövdesine çapraz olarak takılmıştır.

Kayseri Herakles lahdi bu tasvir özellikleriyle Konya Arkeoloji Müzesi'nde bulunan Yunuslar Lahdi (Boysal, 1958: 78) ve Antalya Arkeoloji Müzesi'nde bulunan Herakles Lahdi (Özoral, 1977: 145 vd.) ile benzerdir. Yunuslar Lahdi, Kayseri'de olduğu üzere Herakles'in genç ve sakalsız betimlerinden sakallı ve olgun yaşlarındaki haline geçen kronolojik bir ilerleme gösterir. Fakat Yunuslar Lahdi'ndeki betimlerde Herakles'in vücudunun oldukça kaslı ve hareketlerinin çok daha keskin geçişli olduğu dikkati çeker. Ancak Antalya Herakles Lahdi, Kayseri Lahdi ile oldukça yakın tipolojik benzerlikler taşımaktadır. Bu iki lahit aynı atölye ve/veya heykeltıraşların eserleri olmalıdır. Özellikle Herakles'in genç halinden olgun yaşlarına doğru giden ilerleyişi, vücudun kaslı betimlenişi, hareketlerindeki yumuşak geçişler her iki lahitte de benzerdir. Bu nedenle özellikle figürlerin betimlerinde aynı heykeltıraşın çalışmış olması yüksek ihtimaldir. Buna göre lahit tipolojik özellikleri ve karşılaştırma yapılan eserler yoluyla MS. 2. yüzyıla tarihlendirilmektedir (Cırtıl ve Altuncan, 1993: 31).

\section{Caesarea Heykelciği}

Kapadokya' da Herakles kültüne yönelik heykeltıraşlık eserlerinin bir başka, tartışmalı ve bölgede ne şekilde bulunduğu bilinmeyen bir örneğini de The Walters Art Museum'da bulunan heykelcik oluşturur (The Walters, t.y.). Müzenin 54.764 envanter numaralı bu heykelciğinde aslan postuna sarınmış bir şekilde yaşlı Herakles betimlenmiştir (Levha 3). Envanter bilgilerine göre heykelciğin buluntu yeri Kapadokya'nın merkezi olan Caesarea'dır. The Walters Art Museum'un Akdeniz Eserleri görevlisi Dr. Lisa M. Anderson-Zhu'nun (09 Aralık, 2019) aktarımı yoluyla edinilen envanter bilgilerine göre bu eser, Henry Walters tarafından Dikran Kelekian isimli bir Amerikan vatandaşından satın alınmıştır. Kelekian'ın o dönemde aktardığına göre heykelciğin sadece Caesarea kentinde bulunmuş olduğu bilgisi mevcuttur. Bu nedenle bu heykelciğin geldiği yer, ortaya çıkma şekli kesin olarak bilinemediği için sadece tipolojik bir değerlendirmeye tabi tutulmuş̧ur.

Bronz döküm bu heykelciğin boyutları 43×23.8x14 cm'dir. Bu heykelcik, orijinali MÖ. 3 . yüzyıla tarihlendirilen bir Roma kopyasıdır. Ayakta duran yaşlı Herakles, dinlenen ve sakin bir görüntüde betimlenmiştir. Alın üzerine dökülen saç buklelerini yaldızlı bir saç bandı kuşatmaktadır. Yaşlı ve yorgun ifadesi, yüzünün detaylarına ustaca yerleştirilmiştir. Düşük orbital, kalın, yağlı derisi ve derin nasolabial deri hatt1 yorgunluğunu ifade etmektedir. Eserin gözleri gümüşten yapılmıştır. Gövdesinin üst kısmı oldukça iri ve kaslı bir görüntüdedir. Ancak bu heybetli vücudunun üzerine 
sarındığ 1 aslan postunun derisi oldukça ince ve gergin bir şekildedir. Böylece yaşlı Herakles'in vücudunda sanatsal bir zıtlık işlenmiştir. Sağ kolu ve eli tamamen sarındığı postun altındadır. Aslan postu, sol eli açıkta olacak şekilde yine kolunu kapatmıştır. Başı olmayan aslan postunun dolgun yeleleri kısa bir şekilde aşağıya doğru bırakılmıştır. Bu tipolojik özellikleri ile eser, MÖ. 1. yüzyıl ile MS. 1. yüzyıl aralığına tarihlendirilmektedir (The Walters, t.y.). Bu eserin çok yakın bir benzeri ise 23.74 envanter numarası ile yine aynı müzede bulunan mermer bir heykelciktir (The Walters, t.y.). Ne yazık ki bu eserin de buluntu yeri ve kökeni bilinmediği, sadece analojik tanımlaması yapılabildiği için Caesarea ile olan bağlantısı ya da bölgeye ait bir eser olup olmadığı konusunda net bir fikir belirtmek mümkün değildir. Ancak her iki eser de tipolojik olarak benzer özellikler göstermekte olduğu için aynı bölgeden çıkma olmalıdır. Sonuç olarak bu değerlendirme ve envanter bilgilerine göre heykelciğin Kapadokya'da Herakles kültü içinde olup olmadığı konusunda kesin bir yargıya varmak oldukça güçtür. Sonraki yıllarda yapılacak arazi çalışmalarında heykelciğin Caesarea'ya ya da bölgeye ait olduğu ile ilgili yeni verilerin ortaya çıkması ile ancak bu durum söz konusu olabilir.

\section{Epigrafik Buluntular}

\section{Hanisa (Anisa) Dekreti}

Herakles kültünün varlığına dair en erken epigrafik buluntu, V. Ariarathes zamanına ait bir dekrettir (Levha 4). Kayseri yakınlarındaki Hanisa'da bulunan bu dekrette $(44.7 \times 32.5 \mathrm{~cm})$ halkına yararlı işlerde bulunan Abbas'in oğlu Apollonios'un Konsey ve Halk Meclisi tarafindan onurlandırılışı ve bu nedenle alınan kararlar belirtilmiştir. MÖ. 160 yılına tarihlendirilen bronz bir plaka üzerine Yunanca yazılı bu dekrette Apollonios'un "Zeus Soteros ve Herakles bayramlart ile yıllık ve aylık resmi toplantılar sırasında düzenli olarak taçlandırılmasına..." dair verilen karar belirtilmiş̧ir (Cassayre, 2014: 190 vd.; Hakman, 2015: 154). Buna göre bu onurlandırma sayesinde Herakles kültünün varlığının yanı sıra, bölgede bu inancın bir tanrı mertebesinde olduğu anlaşılmaktadır.

Yazıta göre bahsi geçen Herakles bayramlarının yeri ve zamanı belli değildir. Fakat buluntu yeri ve bölgenin başkenti olması sebebiyle Caesarea'da olması muhtemel gözükmektedir. Ayrıca Yunan'da gymnasionlarda düzenlenen Herakles inancı ile ilgili ritüellerin Zeus tapınaklarında da gerçekleştirilme geleneği düşünüldüğünde, Hanisa yazıtında bahsi geçen bu ritüel, bölgede yaygın bir kültü olduğu bilinen Zeus (Soteros) Tapınağı'nda düzenlenmiş olmalıdır ${ }^{15}$.

\section{Tyana Yazitı}

Herakles kültü ile ilgili bir diğer yazıt Tyana'da bulunmuştur. MÖ. 1. yüzyıla tarihlendirilen yazıt, Hellenistik Dönem Kapadokyasında VI. Ariarathes'in krallığı zamanına aittir:

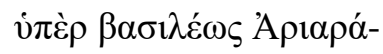

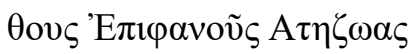

$$
\begin{aligned}
& \Delta \rho v \eta v 0 \tilde{~ \gamma o \mu v \alpha \sigma i \alpha \rho \chi \eta ́ \sigma \alpha \varsigma}
\end{aligned}
$$

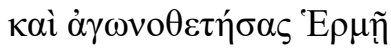

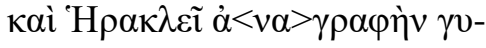

$$
\begin{aligned}
& \mu v \alpha \sigma i \alpha ́ \rho \chi \omega v \text { ảmò } \tau 0 \tilde{v}
\end{aligned}
$$

\footnotetext{
15 Özellikle Erken Klasik Dönem'den itibaren ordunun askeri başarıları için Zeus tapınaklarında kahraman adına ritüeller yapıldığı ya da kahramanın heykelciklerinin adandığı bilinmektedir. Ayrıca bu dönemde mimariye bağlı kabartmalarda özellikle Zeus tapınaklarında Herakles' in mitolojik hikayelerine yer verildiği görülür (Cohen, 1994: 695). Bu heykeltıraşlık uygulaması, ordunun zaferle sonuçlanan ya da sonuçlanmasının umulduğu mücadelede büyük motivasyon kaynağı olmuştur. Bu, özellikle bu dönemde Perslerle yapılan ve ağır kayıpların verildiği mücadeleler nedeniyle bilinçli bir tercih olmalidir.
}

www.turkishstudies.net/social 
$\varepsilon^{\prime}$ ह̌ं

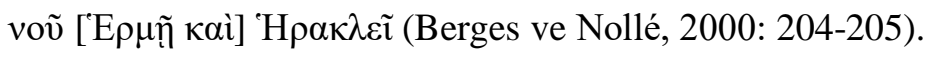

Yazitta Hermes ve Herakles onuruna düzenlenen bir agondan bahsetmektedir ${ }^{16}$. Bu iki tanrı adına gerçekleştirilen agonlar çoğunlukla gymnasionlarla ilişkilidir. Dolayısıyla bölgenin iki önemli yerleşiminde bulunan bu yazıtlar, Herakles kültünün Hellenistik Dönem'de yerleşik bir yap1 gösterdiğini ortaya koymaktadır. Yunan geleneğine göre özellikle gymnasiumlarda sporcuların ya da askeri eğitim alan gençlerin motivasyonunu artırmak ve zafer kazanmaları maksadıyla Herakles adına dört yılda bir festivallerin ve kutsal ziyafetlerin düzenlendiği bilinmektedir. Bu yazıtlar yoluyla bu geleneği Kapadokya Bölgesi'nin de sürdürdüğü anlaşılmaktadır.

Kapadokya'nın Hellenistik siyasetin hakimiyetine, kültürüne ve sanatına başlangıçta direndiği düşünülürse, Herakles kültünün MÖ. 2. yüzyılda ortaya çıkmış olabileceği öngörülebilir. Özellikle V. Ariarathes'in Hellen propogandası bu açıdan etkili olmuştur. Böylece bölgenin Hellenistik kralları hakimiyetlerini Herakles'in yarı tanrısal ve kahramansal yapısından hareketle perçinlemek istemiş olmalıdır.

\section{Numizmatik Buluntular}

Caesarea ve Tyana'da farklı dönemlere ait ortaya çıan sikkeler üzerinde Herakles ve atribüsü olan budaklı ya da budaksız lobut betimi görülmektedir. Herakles'e yönelik en erken sikke örnekleri Caesarea'da Hellenistik Dönem sonunda, Arkhelaos zamanına aittir. Bu dönem, esasında bölgenin Roma vassalı olduğu bir zamana denk gelmektedir. Ayrıca her iki kentte de Roma İmparatorluk Dönemi'nde Herakles ile ilgili verilerin daha çok numizmatik veriler olduğu görülmektedir. Sikkelerin sosyal, siyasi, mimari, dini yapıs1 gibi toplumun karakterini yansıtmas1 bakımından oldukça önemli veriler olduğu düşünüldüğünde mevcut sikkeler bölgede Herakles kültünün yerleşik yapısını ve sürekliliğini ortaya koymaktadır.

Caesarea'nın Arkhelaos dönemindeki otonom bronzlarında, sikkenin ön yüzünde Herakles başı, arka yüzünde lobutu; ya da ön yüzde lobutun, arkada bir çelengin içinde yayın olduğu tipler görülür (Sydenham 1978: 26). Ön yüzde Herakles'in olduğu örneklerde boynuna aslan postu bağlıdır. MÖ. 25-24 yıllarına tarihlendirilen bir sikkede ön yüzde Herakles'in olgun yaşlarda görülen baş1 yer alırken, arka yüzde tetrastil bir tapınak vardır ve alınlığının üç köşesine üç heykel/figür yerleştirilmiştir (Sydenham, 1978: 29; Wroth, 1899: 45). Bu tapınak Herakles adaklarının yapıldığ 1 ya da ziyafetlerinin verildiği bilinen Zeus Tapınağı olmalıdır. Herakles'in Zeus ile olan bu bütünleşik kültünün bir başka örneğinde ise Argaios Dağı ile karş1laş1lır. MÖ. 9-8 y1llarına tarihlendirilen, ön yüzünde Herakles başının yer aldığg bir sikkenin arka yüzünde Argaios Dağı ve zirvesinde Zeus'un kartalının olduğu tip görülür (Sydenham, 1978: 29). Öyle anlaş1lıyor ki Herakles kültünün uygulamaları baş tanrı Zeus'tan bağımsız olmamıştır. Ayrıca kült imajının bu dönemde kullanılmasının esas nedeni, dönemin son kralı Arkhelaos'tur. Pontus Kapadokyası'nın başrahibi Arkhelaos'un oğlu olan Arkhelaos (Sisines) yönetime geldiğinde soyunu Herakles oğlu Temenos'a dayandırmış ve sikkeler üzerinde Herakles'i kullanmıştır (Wroth, 1899: xxxiii). Esasında soyun Herakles'e dayandırılması Hellenistik Dönem'in en yaygın geleneklerinden biridir ve Kapadokya Bölgesi de bu tanrısal geleneğe dahil olmuştur.

Şimdiye kadar ele geçen verilere göre Arkhelaos'tan sonra Herakles ile ilgili betimlere rastlanmaz. Roma İmparatorluk Dönemi'nde en erken Herakles ya da lobutunun yer aldığı sikke tipleri Domitianus zamanında ortaya çıkmıştır. MS. 91-92 yıllarına tarihlenen Domitianus sikkesinin arka yüzünde Herakles' in lobutu görülür (Sydenham, 1978: 51). Arka yüzde lobutun olduğu ve MS. 98-99 yıllarına tarihlendirilen bir diğer sikke Traianus zamanına aittir (Sydenham, 1978: 59). Aynı

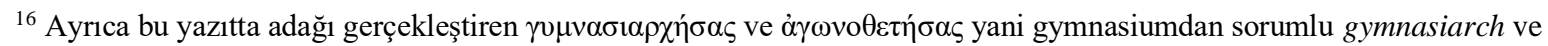
yarışmalardan sorumlu memur agonothetes Tyana' da bu dönemde bir gymnasiumun varlığını kanıtlamaktadır.
} 
döneme ait bir başka sikkenin arka yüzünde ise Herakles'in sakalsız başı yer alır. Herakles'in boynunda aslan postunun bağlı olduğu görülmektedir (Sydenham, 1978: 62). Hadrianus zamanına ait, MS. 120-121 yıllarına tarihlendirilen bir hemidrahminin ve MS. 121-122 yıllarına tarihlendirilen bir drahminin arka yüzünde ise lobut yer alır (Levha 5) (Sydenham, 1978: 76; Wroth, 1899: 61). Bu y1llarda lobutun ay ve yıldız ile beraber betimlendiği arka yüz tipleri de mevcuttur (Sydenham, 1978: 78; Wroth, 1899: 61). Arka yüzde lobutun olduğu diğer sikke örnekleri Antoninus Pius, Marcus Aurelius ve Commodus zamanlarına aittir (Sydenham, 1978: 81, 86, 91, 98; Wroth, 1899: 67, 71). Yıldız ve ay simgelerinin Doğu, özellikle de Pers dini karakterini yansıtan bir simge olduğu düşünüldügünde, lobut ile beraber yer alan yıldız ve ay motifleri Herakles inancının Pers inanc1 etkisinde kalan yerel bir yapı göstermiş olabileceğini düşündürür. Ayrıca bu konuda Berges ve Nollé (2000) Herakles'in Kapadokya'da Zeus ve Astarte'nin çocuğu olan bir kimlikte olabileceğini öne sürmüş olması, bu sikke yoluyla konuyu tartışmaya açı bir hale getirmektedir.

Tyana'da ise Hadrianus, Septimus Severus (Levha 6) ve Iulia Domna (Levha 7) sikkeleri üzerinde lobut ve Herakles tipleri karşımıza çıkar. Hadrianus dönemine ait bir sikkenin arka yüzünde Herakles'in lobutu yer alır (Berges ve Nollé, 2000: tafl. 123.16). Septimus Severus dönemine ait bir sikkenin arka yüzünde ise ayakta duran ve çıplak olarak betimlenmiş Herakles, sağ eliyle lobutunu tutarken, sol elinden aşağıya aslan postu sarkmaktadır. Ayrıca yine Tyana'da Iulia Domna sikkesi üzerinde ise kahramanın yorgun Herakles tipi yer alır. Sağ kolunu arkasına götürmüş, sol kolunda aslan postu ve lobutuna yaslanarak betimlenmiştir (Berges ve Nollé, 2000: tafl. 125.46). Yaslandığı lobutun altında ise bir boğa başı bulunmaktadır. Dolayısıyla yorgun Herakles tipinde görülen bu tasvir, özellikle alt kısımda yer alan boğa başından dolayı Tyana'da bulunan Herakles heykeli ile benzer görünmektedir. Buna göre bu veriler kentte yer alan bir kült heykelini işaret ediyor olmalıdır.

\section{Sonuç}

Herakles, Zeus'un oğlu ve yarı tanrısal yapısı itibariyle Yunan inancında farklı bir kült karakteri olarak ortaya çıkmıştır. Kültünün gelişiminde özellikle onun yarı ölümsüz karakterinin, ölümlü insanoğlu için tanrısal bir güç sağlaması etkili olmuştur. Bundan dolayı krallar ya da imparatorlar kendilerini Herakles gibi görmüş, ona öykünmüss, onun atribülerini kullanmışlar; kendilerini Herakles ile reenkarne etmişlerdir. Büyük İskender, VI. Mithridates ve Roma İmparatoru Commodus gibi devlet adamlarının bu dönüşümü kullanarak özellikle heykeltıraşlık eserlerinde kendilerini Herakles pozunda ya da tanrısallığında gösterdikleri bilinmektedir. Herakles'in yarı ölümlü yapısı, ölümlü insanın tanrısal kudretini ve gücünü ortaya çıkarmıştır. Dolayısıyla bu gücü elde etmek adına Herakles adeta bir tanrı gibi de tapınım görmüştür.

Herakles kültünde iki ayrı tapınım şekli ortaya çıkmaktadır. Öncelikle yarı ölümlü ve tanrısal bir kahraman olarak gymnasionlarda (çoğunlukla Hermes ile beraber) tapınım gördüğü bilinir. Herakles bu inanç biçiminde askerlerin, askeri eğitim alanların ve atletlerin koruyucu tanrısıdır. Herakles kültünün bir diğer tapınımı ise onun kent koruyucu tanrı olarak kabul görmesidir. Esasında Herakles'in tanı olarak tapınımının ilk inanç biçiminden gelişerek ortaya çıktığı anlaşılmaktadır. Yine de Herakles, tam anlamıyla bir Yunan tanrısının kült karakterini göstermemiştir. Buna en önemli kanıt, onun adına düzenlenen agonların, ritüellerin özellikle Zeus tapınaklarında gerçekleştirilme geleneğidir. Her iki farklı tapınım şeklinin kökeni Yunan'dır ve kültün bu farklı yapısı Anadolu ve Roma'da da kendini göstermiştir. Bu yayının konusuyla ilgili olarak da bu ikili kült karakteri Kapadokya Bölgesi'nde de görülmektedir.

Kapadokya'da Caesarea ve Tyana'da ele geçen Herakles kültüne yönelik veriler, bölgede yerleşik bir kült olduğunu kanıtlamaktadır. Kültün varlığı hususunda verilerin çeşitlilik ve süreklilik arz etmesi önemlidir. Bölgenin heykeltıraşlık eserleri açısından en erken eseri, Niğde Tepebağları Höyük'ünde bulunan Herakles heykelciğidir. Hellenistik Dönem sonu-Erken Roma Dönemi'ne tarihlendirilen bu eser, esasında tipolojik olarak Hermes ve Herakles tartışmasına açık bir yapı gösterse de anolojik değerlendirmenin Herakles’i işaret etmesinden dolayı Herakles olarak kabul 
edilmiştir. Ayrıca benzer tipolojide Anadolu örnekleri olan bu eser, daha yerel bir biçimlendirme olmalıdır. Bu eser dışında bulunan heykeltıraşlık eserleri Roma İmparatorluk Dönemi'ne aittir. Tyana' da bulunan Herakles heykeli (parçası) bu kültün yapısını göstermesi açısından önemlidir. MS. 2. yüzyıla tarihlendirilen bu eserde Herakles, dinlenen Herakles pozunda olmalıdır. Boğa başının desteklediği aslan postu ve lobutu ile bu eser, Tyana'nın kent koruyucu tanrısının kült heykelidir. Yine Roma İmparatorluk Dönemi'ne tarihlendirilen ve tartışmalı olan bir diğer eser, Caesarea'da bulunduğu dışında herhangi bir araştırma geçmişi olmayan yaşlı Herakles heykelciğidir. $\mathrm{Bu}$ heykelciğin karşılaştırmasının yapılabileceği bir diğer örneğin de buluntu yerinin bilinmemesinden, bölgede benzer örneklerinin olmamasından dolayı kültün karakterine bir açıklık getirecek şekilde değerlendirmeye tabi tutulmamıştır. Eser alışagelmiş yorgun Herakles tiplerine göre hem yüzünün hem de vücudunun yaşlı ve yorgun olarak tasvir edilişi bakımından dikkati çekmektedir. $\mathrm{Bu}$ heykeltıraşlık eserleri dışında Herakles'in 12 işinin anlatıldığı, Caesarea'da bulunan Pamphylia tipi frizli bir lahit bulunmaktadır. Bu lahit, Herakles'in on iki işinin tasvirinde tanrısal kahramanın kendisinin kronolojik olarak ilerleyişini göstermesi açısından da oldukça önemlidir. Elbette bir lahit üzerinde Herakles'in tasvirlerinin kullanılması onun bölgedeki inancının varlığına da işaret eden önemli bir göndermedir.

Epigrafik veriler bakımından en erken eser ise MÖ. 160 y1lına tarihlendirilen Hanisa dekretidir. Bu kararnamede Herakles adına düzenlenen bayramlardan söz edilmesi, kültün yerleşik varlığına işaret etmesi açısından oldukça önemlidir. Ayrıca Herakles onuruna düzenlenen agonun aynı yazıtta bahsi geçen Zeus Stratios'tan dolayı onun tapınağında düzenleniyor olması muhtemel görünmektedir. Herakles ritüellerinin Zeus tapınaklarında düzenlenme geleneği bu ihtimali güçlü kılmaktadır. Bir diğer epigrafik veri olan, MÖ. 1. yüzyıla tarihlendirilen Tyana yazıtı da bu yerleşik inancın yayılımını ve yine aynı zamanda devamlılığını göstermesi bakımından önemlidir. Her iki yazıtta da Herakles onuruna bölgenin kentlerinde düzenlenen şenliklerden haberdar olmamıza rağmen, bunların ne zaman ve nerede düzenlendiği, ritüellerin içeriğinin ne olduğunun bilinmeyişi önemli bir eksikliktir.

Numizmatik verilerde omuzuna aslan postu bağlanmış Herakles başı, lobut ya da aslan postuyla betimlenen dinlenen Herakles tipleri görülmektedir. Bölgede Herakles tasvirinin görüldüğü en erken sikke, Caesarea'da ortaya çıkar ve Hellenistik Kapadokya'nın son kralı Arkhelaos zamanına aittir. Roma İmparatorluk Dönemi'nde ise Caesarea'da en geç Commodus zamanına kadar aralıklı olarak Herakles ve onunla ilgili betimlerin olduğu sikkeler görülür. Tyana'da ise en erken Hadrianus zamanında görülmeye başlanan tasvirler, en geç Iulia Domna sikkelerinde kendini gösterir. Dolayısıyla bazı dönemlerde görülmemekle birlikte, bölgenin numizmatik verileri en erken Arkhelaos zamanından başlayarak MS. 2. yüzyıla kadar süreklilik göstermektedir. Herakles ile ilgili tüm veriler ele alındığında ise MÖ. 2. yüzyıl ortasından itibaren başlayan verilerin MS. 2. yüzyıla kadar devam ettiği görülür.

Sonuç olarak bölgede Herakles kültü, yoğun Pers etkisinin azalmaya ve Hellenistik kültürün yerleşmeye başladığı MÖ. 2. yüzyıl başlarından itibaren kendini göstermeye başlamıştır. En geç verinin ise Iulia Domna sikkesinde olması sebebiyle MS. 2. yüzyılda dahi varlığını sürdürdüğü anlaşılmaktadır. Ayrıca bu tarih aralığında Herakles, Kapadokya Bölgesi'nde hem tanrısal bir kahraman hem de bir tanrı olarak iki ayrı şekilde tapınım görmüştür.

\section{Teşekkür}

$\mathrm{Bu}$ yayında yer alan Tepebağları Heykelciği için çalışma izni veren Niğde Arkeoloji Müze Müdürü Fazlı Açıkgöz ile Arkeolog Yakup Ünlüler'e teşekkür ederim. Caesarea Herakles Heykelciği'nin müzeye gelişi ve envanter bilgileri konusunda yardımlarını esirgemeyen The Walters Art Museum'un Akdeniz Eserleri görevlisi Dr. Lisa M. Anderson-Zhu'ya teşekkür ederim. 


\section{Kaynakça}

Anlağan, T. (1972). Tepebağları Höyüğünde bulunan tunç bir heykelcik. Anadolu XVI (Anatolia), 113-117.

Ashmolean (t.y.). Standing Heracles. http://collections.ashmolean.org/collection/ search/per_page/ 100/offset/0/sort_by/relevance/object/92136

Ashmolean (t.y.). Figure of Heracles with lion-skin and club. Herakles http://collections.ashmolean. org/collection/search/per_page/100/offset/0/sort_by/relevance/object/29731

Ashmolean (t.y.). Figure of the hero god Heracles with his club seated on a lion. http://collections.ashmolean.org/collection/search/per_page/100/offset/0/sort_by/relevance/ object $/ 30323$

Bartman, E. (1992). Ancient sculptural copies in miniature. E. J. Brill.

Baydur, N. (1994). Anadolu'da kutsal dağlar, dă̆ tanrllar: klasik çă̆. Graphis Yayınları.

Berges, D. ve Nollé, J. (2000). Tyana: archäologisch-historische Untersuchungen zum südwestlichen Kappadokien. Teil I-II, Rudolf Habelt.

Boysal, Y. (1958). Yunuslar Köyü’nde bulunan lahit. Türk Arkeoloji Dergisi VIII/2, 77-81.

Cassayre, A. (2014). La justice sur les pierres. Recueil d'inscriptions à caractère juridique des cités grecques à l'époque hellénistique. http://pascal.delahaye1.free.fr/aude.cassayre/RECUEIL. pdf

Cirtıl, S. ve Altuncan, M. (1993, Ocak-Şubat). Kayseri Herakles lahdi. Kültür, 97, 26-31.

Cohen, B. (1994). From bowman to clubman: Herakles and Olympia. The Art Bulletin 76, 4, 695715.

Coin Project (t.y.). Hadrianus. http://www.coinproject.com/siteimages/589/589-1000-4-105.jpg

Doksanaltı, E. M. (2016). Konya Arkeoloji Müzesi’nden bir Herakles heykelciği: “Herakles Epitrapezios". SEFAS, 36, 467-480.

Ekinci, M., Genç, U. ve Avşar, A. O. (2012). Antalya Müzesi'nde restorasyonu yapılan yorgun Herakles heykeli. 21. Müze Çalışmaları ve Kurtarma Kazıları Sempozyumu, 01-05 Nisan, 107-116.

Erciyas, D. B. (2006). Wealth, aristocracy and royal propaganda under the Hellenistic Kingdom of the Mithradatids in the central Black Sea Region of Turkey. Colloquia Pontica, Vol. 12: Brill.

Firat, M. (2015). Isparta Müzesi'nden bir grup bronz heykelcik. Arkeoloji Dergisi, XX, Ege Üniversitesi Edebiyat Fakültesi Yayınları, 181-194.

Getty Museum. (t.y.). Statue of Hercules (Lansdowne Herakles). http://www.getty.edu/art/collection /objects/6549/unknown-maker-statue-of-hercules-lansdowne-herakles-roman-about-ad125/

Getty Museum. (t.y.). Statuette of Hercules holding the Apples of the Hesperides. http://www.getty. edu/art/collection/objects/6628/unknown-maker-statuette-of-herculeshold ing-the-applesof-the-hesperides-roman-2nd-3rd-century-ad/

Hakman, M. (2015). Kapadokya'da Zeus kültü. Arkeoloji ve Sanat Yayınları.

Howard, S. (1978). The Lansdowne Herakles. The Getty Museum Publications. 
Hsing, I. ve Crowell, W. (tr.) (2005). Heracles in the east: the diffusion and transformation of his image in the arts of Central Asia, India, and Medieval China. Asia Major, 18(2), third series, 103-154.

Işın, G. (2007). Patara terrakottaları: Hellenistik ve Erken Roma dönemleri. Patara V.1. Ege Yayınları.

Kızgut, İ. (2004). Türkiye'nin seçilmiş bazı müzelerinden Hellenistik ve Roma dönemi bronz heykelcikleri. Yayınlanmamış doktora tezi, Akdeniz Üniversitesi Sosyal Bilimler Enstitüsü.

Martialis. Epigrammata. W. Heraeus, J. Borovskij (Ed.). Leipzig, 1925/1976. http://www.perseus. tufts.edu/hopper/text?doc=Perseus\%3Atext\%3A2008.01.0506\%3Abook\%3D9\%3Apoem\% $3 \mathrm{D} 45$

Metin, H. (2016, Nisan). Pisidia'dan kurşun bir Herakles heykelciği üzerine bazı gözlemler. Uluslararası Sosyal Araştırmalar Dergisi, 9/43, 1138-1143.

Murray, A. S. (1882). Herakles Epitrapezios. The Journal of Hellenic Studies, Vol. 3, 240-243.

Musei Capitolini (t.y.). Bust of Commodus as Hercules. http://www.museicapitolini. org/en/percorsi/percorsi_per_sale/museo_del_palazzo_dei_conservatori/sale_degli_horti_la miani/busto_di_commodo_come_ercole

Mutlu, S. (2016). Tanrıça Ma (Mõ) ve Kappadokia Komana’sı. Phaselis, vol. 2, 311-322.

Özoral, F. (1977). Herakles lahdi. Türk Arkeoloji Dergisi, XXIV/1, 145-153.

Özsait, M. ve Özsait, N. (2011). 2009 y1lı Isparta ve Burdur yüzey araştırmaları. 28. Araştırma Sonuçları Toplantısı, 2. Cilt, 24-28 May1s 2010, İstanbul, 41-56.

Pache, C. O. (2010). Hero and god in Greek religion. M. Gagarin (Ed.), E. Fantham (Ch. Ed.). The Oxford Encyclopedia of Ancient Greece and Rome, vol. 3, Oxford University Press, 398-404.

Palagia, O. (1984). The Hope Herakles reconsidered. Oxford Journal of Archaeology, 3(1), 107-126.

Palagia, O. (1990, March). Two statues of Hercules in the Forum Boarium in Rome. Oxford Journal of Archaeology, Vol.9/1, 51-70.

Pollit, J. J. (1986). Art in the Hellenistic age. Cambridge University Press.

Salta, M. (2019). Under the care of Daemons: from the Athenian Acropolis to Kallirrhoe on the Ilissos. Ascending and Descending the Acropolis: Movement in Athenian religion, Wiebke Friese, Soren Handberg, Troels Myrup Kristensen (Eds.). Aarhus University Press, 63-102.

Stafford, E. (2010). Herakles between gods and heroes. J. N. Bremmer, A. Erskine (eds). The Gods of Ancient Greece: Identities and Transformations, Edinburgh Leventis Studies 5, Edinburgh University Press, 228-44.

Statius, P. Papinius. Silvae. J. H. Mozley (Ed.). London: William Heinemann; New York: G. P. Putnam's Sons., 1928. http://www.perseus.tufts.edu/hopper/text?doc=Perseus\%3Atext \%3A 2008.01.0499\%3Abook\%3D4\%3Apoem\%3D6

The Walters (t.y.). Aged Herakles. https://art.thewalters.org/detail/37884/aged-herakles/

The Walters (t.y.). Hercules. https://art.thewalters.org/ detail/27325/hercules/

Wroth, W. (1899). Catalogue of the Greek coins of Galatia, Cappadocia and Syria. Catalogue of the Greek coins in the British Museum, The Trustees.

Yaman, İ. D. (2019). Kapadokya'da Paleolitik araştırmalar. Kapadokya: Hafiza, Kimlik ve Kültürel Miras, M. Hakman (ed.), Arkeoloji ve Sanat Yayınları, 9-32. 


\section{Levhalar}
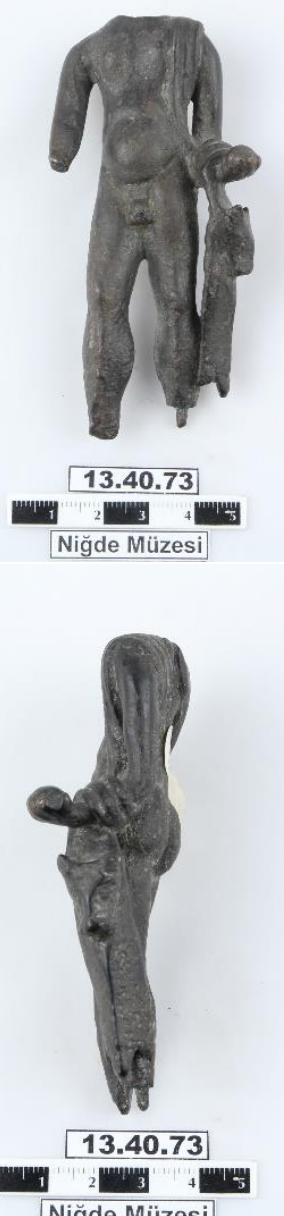

Levha 1. Tepebağları Heykelciği

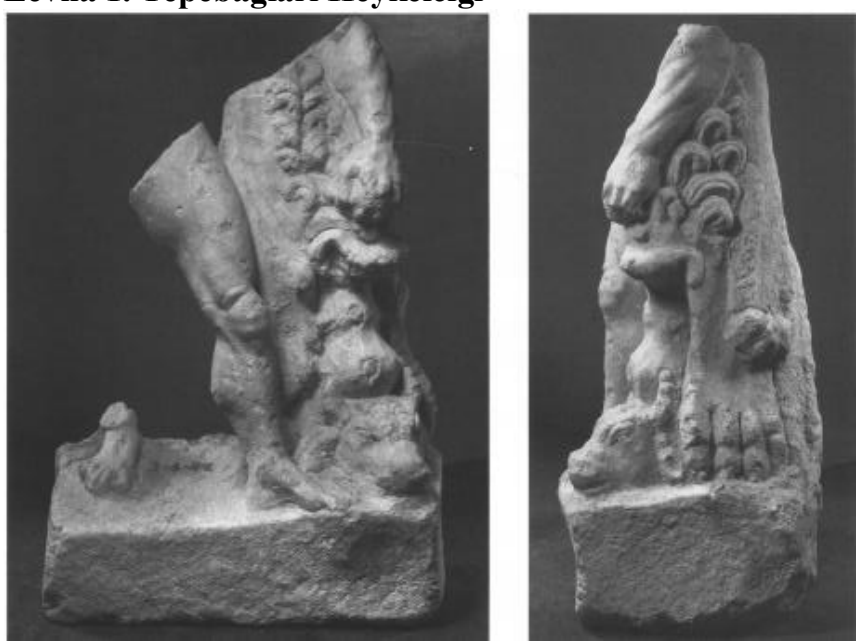

Levha 2. Tyana Herakles Heykeli (parçası) (Berges, 2000: taf. 59)
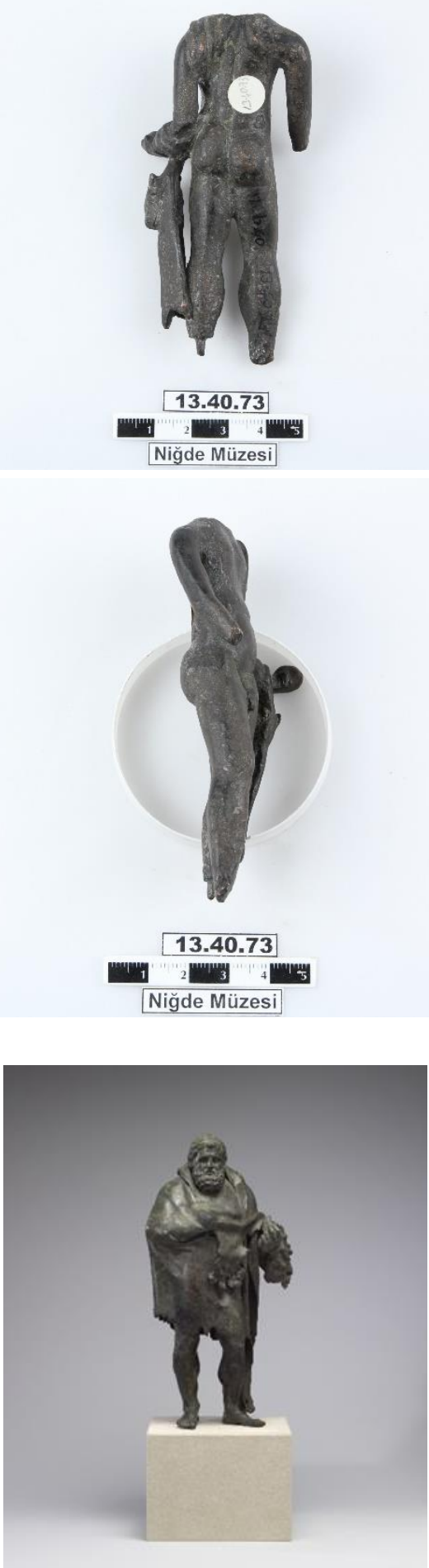

Levha 3. Caesarea Herakles Heykelciği (The Walters, (t.y.)) 


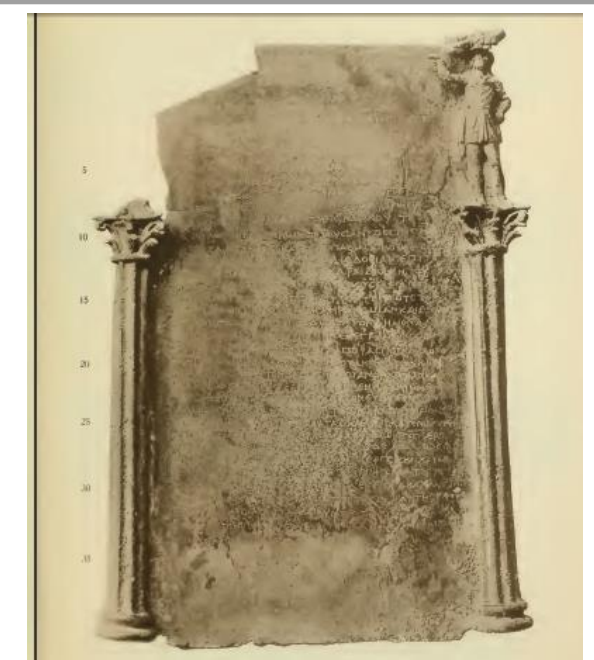

Levha 4. Hanisa Dekreti (Hakman, 2015: 157)
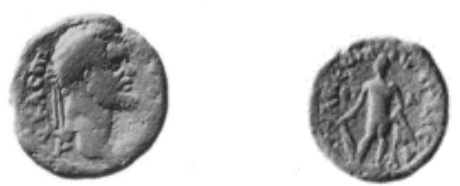

Levha 6. Septimus Severus Dönemi Tyana sikkesi (Berges, 2000: taf. 124, 24)

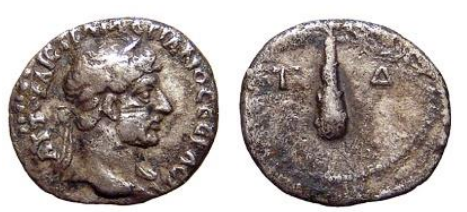

Levha 5. Hadrianus Dönemi sikkesi (Coin Project, t.y.)

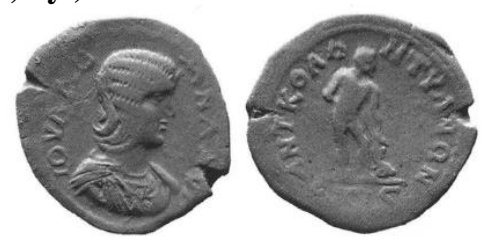

Levha 7. Iulia Domna sikkesi (Berges, 2000: taf. 125, 46) 